\title{
Pre-meal and postprandial lipaemia in subjects with the metabolic syndrome: effects of timing and protein quality (randomised crossover trial)
}

\author{
Ann Bjørnshave ${ }^{1,2_{*}}$, Trine Nygaard Johansen ${ }^{1}$, Bashar Amer ${ }^{3}$, Trine Kastrup Dalsgaard ${ }^{3}$, Jens Juul Holst ${ }^{4}$ \\ and Kjeld Hermansen ${ }^{1}$ \\ ${ }^{1}$ Department of Endocrinology and Internal Medicine, Aarbus University Hospital, Aarbus, Denmark \\ ${ }^{2}$ Danish Diabetes Academy, Odense, Denmark \\ ${ }^{3}$ Department of Food Science, Aarhus University, Tjele, Denmark \\ ${ }^{4}$ Department of Biomedical Sciences, NNF Centre for Basic Metabolic Research, University of Copenhagen, \\ Copenhagen, Denmark
}

(Submitted 12 June 2018 - Final revision received 28 September 2018 - Accepted 19 October 2018)

\section{Abstract}

Non-fasting TAG - postprandial lipaemia (PPL) - are to a higher degree associated with cardiovascular risk compared with fasting TAG. Dietary protein, especially whey proteins (WP), may lower PPL. We hypothesised that a WP pre-meal (17.6 g protein) consumed $15 v .30 \mathrm{~min}$ before a fat-rich meal reduces the PPL response in subjects with the metabolic syndrome (MetS) and that a WP pre-meal has more potent effects than casein and gluten pre-meals. A total of sixteen subjects with the MetS completed an acute, randomised, crossover trial. WP premeals were consumed 15 and $30 \mathrm{~min}$, and casein and gluten $15 \mathrm{~min}$ before a fat-rich meal. Blood samples were drawn 360 min postprandially to determine metabolite and hormone responses, S-paracetamol (for assessment of gastric emptying) and amino acids. Insulin and glucagon responses were affected by both timing and protein type (for all $P<0 \cdot 01$ ), with significantly higher concentrations for WP given at -15 min than WP at $-30 \mathrm{~min}$ and higher responses compared with gluten for the first 30 min after pre-meal consumption (for all $P<0 \cdot 05$ ). The PPL responses changed neither by timing nor by protein type. Glucose-dependent insulinotropic peptide but not glucagon-like peptide 1 responses differed between the three protein types. S-paracetamol concentration was higher for WP ( $-30 \mathrm{~min})$ than for WP ( $-15 \mathrm{~min}) 15 \mathrm{~min}$ after the main meal $(P=0.028)$, and higher for casein and gluten than for WP at time point $30 \mathrm{~min}$ (for all $P<0.05)$. In conclusion, the PPL response was not changed by ingestion of a $17.6 \mathrm{~g}$ protein pre-meal, whereas both timing and protein quality affected hormone secretion (insulin and glucagon).

Key words: Pre-meal lipaemia: Whey proteins: Protein quality: Timing: Metabolic syndrome: Postprandial lipaemia

The metabolic syndrome (MetS) is a cluster of risk factors for development of atherosclerotic CVD and type 2 diabetes (T2D) that encompass abdominal obesity, insulin resistance, hypertension and dyslipidaemia ${ }^{(1)}$. Thus, hypertriacylglycerolaemia is a characteristic feature of the MetS. Recent studies have demonstrated that CVD is more strongly associated with increased levels of TAG in the non-fasting state, that is, postprandial lipaemia (PPL), compared with the fasting state ${ }^{(2,3)}$.

Diet is one of the most important modifiers of PPL. A century ago, Staub ${ }^{(4)}$ and Traugott ${ }^{(5)}$ noted that glucose tolerance improved after the second of two consecutive glucose challenges, the so-called Staub-Traugott effect. In continuation of this finding, it turned out that consumption of whey proteins (WP) from milk before ingestion of carbohydrate diets was associated with enhanced insulin responses to these diets. Thus,
WP pre-meals significantly reduce glycaemic responses ${ }^{(6-9)}$, delay gastric emptying ${ }^{(8,10)}$ and stimulate glucagon-like peptide 1 (GLP-1) secretion ${ }^{(10)}$; and WP is more effective in this respect compared with other proteins ${ }^{(11-13)}$. WP pre-meals give rise to a pronounced increase in the plasma concentrations of lysine, threonine and branched-chain amino acids (BCAA) (leucine, isoleucine and valine) ${ }^{(11)}$. These amino acids (AA) and BCAA in particular mimic the insulinotropic properties of $\mathrm{WP}^{(14)}$. In subjects with and without T2D, WP as part of a fat-rich meal also reduces PPL compared with casein, cod and gluten proteins $^{(15,16)}$. In addition, we recently demonstrated the difference between 0 and $20 \mathrm{~g}$ WP consumed as a pre-meal before a fat-rich main meal ${ }^{(17)}$. Even though a pre-meal of $20 \mathrm{~g}$ of WP did not influence PPL in this study ${ }^{(17)}$, we cannot exclude that pre-meals with other protein sources may influence PPL. We

Abbreviations: AA, amino acid; BCAA, branched-chain amino acid; E\%, energy percentage; GIP, glucose-dependent insulinotropic peptide; GLP-1, glucagonlike peptide 1; iAUC, incremental AUC; PPL, postprandial lipaemia; WP, whey protein.

* Corresponding author: A. Bjørnshave, fax + 45 86193807, email ann.bjoernshave@clin.au.dk 
therefore hypothesised that different protein pre-meals differentially affect PPL after ingestion of a fat-rich meal in subjects with the MetS. We aimed to compare the impact of a small dose ( $17.6 \mathrm{~g}$ pure protein) of WP with that of casein and gluten protein. We also wanted to investigate whether the time span between the pre-meal and the main meal influences PPL responses. We hypothesised that a WP pre-meal would elicit a lower PPL response if consumed 15 min before a fat-rich meal than if consumed $30 \mathrm{~min}$ before a meal.

\section{Methods \\ Participants}

A total of twenty-eight subjects were recruited from August 2014 to January 2015 through local newspapers. All interested subjects were screened for the MetS as defined by the International Diabetes Federation ${ }^{(1)}$. We included women and men above 18 years with the MetS and having had a stable weight for at least 3 months. Exclusion criteria are abnormal TAG (>5 mmol/l) or blood pressure $(160 / 100 \mathrm{mmHg}$ ); clinically significant CVD; renal, liver or endocrine disease; diabetes; alcohol or drug abuse; current treatment with steroids; pregnancy and lactation; or a significant psychiatric medical history. Regular medication was accepted if the dose had been stable for a minimum of 4 weeks and could be continued throughout the study period. A total of eleven subjects were taking antihypertensive therapy and nine were being treated with cholesterol-lowering medication. A total of six women and ten men completed the study. All subjects provided their written informed consent. The protocol was approved by the Central Denmark Region Committees on Health Research Ethics (ID: 1-10-72-189-14), and the trial was performed in accordance with the Declaration of Helsinki. The study was registered with ClinicalTrials.gov (ID: NCT02228252).

\section{Design}

The present study was an acute, randomised, crossover study with four arms. The four test days were separated by washout periods of approximately 1 week where subjects consumed their habitual diets. The subjects were randomly allocated to the four test meals according to a randomisation list made on www. randomization.com. On a full day before each test day, the subjects consumed a ready-prepared standard diet (20\% energy (E\%) as protein, $54 \mathrm{E} \%$ as carbohydrates and $26 \mathrm{E} \%$ as fat). Women had a diet containing of $7000 \mathrm{~kJ}$ and men $9000 \mathrm{~kJ}$. Before the test day, subjects were asked to avoid alcohol, demanding physical activity and painkillers containing paracetamol.

After a $12 \mathrm{~h}$ overnight fast, the participants arrived to our clinic (Aarhus University Hospital, Aarhus, Denmark). A catheter was inserted in a cubital vein for collecting fasting blood samples, and urine sample and anthropometric measurements were obtained. Subsequently, the participants consumed a pre-meal, waited 15 or $30 \mathrm{~min}$ and ingested a fat-rich meal within $15 \mathrm{~min}$. During the entire test period, the participants were allowed to drink $200 \mathrm{ml}$ tap water.

\section{Test meals}

Participants consumed pre-meals with three different protein types (WP, casein and gluten proteins) $15 \mathrm{~min}$ before the fatrich meal. The pre-meals contained equivalent amounts of pure protein $(17 \cdot 6 \mathrm{~g}$ ), which corresponds to $20 \mathrm{~g}$ WP isolate. As the fourth intervention, a WP pre-meal was given $30 \mathrm{~min}$ before the fat meal. The pre-meals were not blinded. Blood samples were drawn at the following time points: -15 (only when pre-meal was consumed $30 \mathrm{~min}$ before the main meal), -10 and $0 \mathrm{~min}$. The nutrient composition and the relative AA compositions of the protein powders are listed in Table 1. We used a WP isolate (Lacprodan DI-9224 Instant; Arla Foods Ingredients Group P/S). The casein powder was a sodium caseinate spray dried from pure milk protein (Miprodan ${ }^{\circledR}$ 30; Arla Foods amba). A total amount of $17.6 \mathrm{~g}$ pure protein (20 g WP and $19 \mathrm{~g}$ casein) was blended with $200 \mathrm{ml}$ tap water and $30 \mathrm{~g}$ frozen strawberry. WP and casein were served drinkable. The gluten protein powder (wheat gluten; Reppe Lantmännen) was insoluble in cold water. Therefore, $21 \mathrm{~g}$ of total gluten protein was blended with $50 \mathrm{ml}$ water and $30 \mathrm{~g}$ strawberry. The mixture was eatable with a teaspoon and served with $150 \mathrm{ml}$ water.

A standardised, fat-rich breakfast meal was served at time point $0 \mathrm{~min}$. The meal consisted of white bread, rye bread, butter, cheese, salami, bacon, egg, milk and decaffeinated coffee. The energy composition was $17 \mathrm{E} \%$ as protein, $15 \mathrm{E} \%$ as carbohydrates and $68 \mathrm{E} \%$ as fat. The fat composition was $47 \cdot 8 \%$ from SFA, $27 \cdot 8 \%$ from MUFA and $6.5 \%$ from PUFA. The total

Table 1. Nutrient composition and the relative amino acid composition of the three protein powders

\begin{tabular}{|c|c|c|c|}
\hline & \multicolumn{3}{|c|}{ Protein type } \\
\hline & Whey & Casein & Gluten \\
\hline \multicolumn{4}{|l|}{ Nutrient composition* } \\
\hline Amount of protein powder $(\mathrm{g})$ & 20 & 19 & 21 \\
\hline Total protein $(\mathrm{g})$ & $17 \cdot 6$ & $17 \cdot 6$ & 17.6 \\
\hline Total fat $(\mathrm{g})$ & 0.3 & 0.1 & 0.4 \\
\hline Total lactose (g) & $<0.02$ & $<0.06$ & - \\
\hline Total energy (kJ) & $310 \cdot 6$ & $305 \cdot 0$ & 314.0 \\
\hline \multicolumn{4}{|c|}{$\begin{array}{l}\text { Amino acid composition adjusted to WP (100) } \\
\text { (relative }(\mathrm{g})) \dagger\end{array}$} \\
\hline Ala & 100 & 45 & 59 \\
\hline Asp (Asn) & 100 & 108 & 193 \\
\hline Cys & 100 & 0 & 83 \\
\hline Glu (Gln) & 100 & 90 & 174 \\
\hline Gly & 100 & 52 & 98 \\
\hline His & 100 & 99 & 98 \\
\hline Ile & 100 & 49 & 45 \\
\hline Leu & 100 & 58 & 55 \\
\hline Met & 100 & 84 & 66 \\
\hline Phe & 100 & 106 & 147 \\
\hline Pro & 100 & 764 & 908 \\
\hline Ser & 100 & 77 & 135 \\
\hline Thr & 100 & 80 & 79 \\
\hline Trp & 100 & 92 & 91 \\
\hline Tyr & 100 & 108 & 87 \\
\hline Val & 100 & 68 & 62 \\
\hline
\end{tabular}


energy content was $3900 \mathrm{~kJ}$. The participants received $1.5 \mathrm{~g}$ paracetamol $\left(3 \times 500 \mathrm{mg}\right.$ tablets of Pinex ${ }^{\circledR} ;$ Actavis $)$ and $100 \mathrm{ml}$ water together with the meal. Blood samples were subsequently drawn postprandially after the main meal at 15, 30, 60, 90, 120, 180, 240 and $360 \mathrm{~min}$

\section{Blood analysis}

All samples were obtained using EDTA except for glucagon (tubes contained EDTA and aprotonin) and samples for serum preparation. The samples were placed on ice immediately after sampling and separated by centrifugation at $2000 \boldsymbol{g}$ for $15 \mathrm{~min}$ at $4^{\circ} \mathrm{C}$. Serum samples were separated from full blood after centrifugation at $2000 \boldsymbol{g}$ for $15 \mathrm{~min}$ at room temperature. All samples were frozen at $-20^{\circ} \mathrm{C}$ and stored at $-80^{\circ} \mathrm{C}$. Plasma insulin was analysed using an ELISA kit (code: K6219; Dako Denmark A/S). Glucagon was measured using a radioimmunoassay kit specific for pancreatic glucagon with glucagon antibody and ${ }^{125}$ I-glucagon (catalogue no. GL-32K; Millipore). The COBAS c111 system (Roche Diagnostics $\mathrm{GmbH}$ ) was used for measurement of TAG, NEFA, glucose and paracetamol in serum. The system used an enzymatic colorimetric method; commercial kits were used for analysis of TAG (ref. no. 04657594190; Roche Diagnostics GmbH) and NEFA (ref. no. 434-91795 and 436-91995; Wako Chemicals GmbH). Plasma glucose was analysed using an enzymatic reference method with hexokinase (ref. no. 04657527190; Roche Diagnostics GmbH). S-paracetamol was quantified using a colorimetric method (ref. no. 03255379 190; Roche Diagnostics GmbH). One subject did not receive paracetamol due to hypersensitivity to paracetamol. GLP-1 and glucose-dependent insulinotropic peptide (GIP) concentrations were measured with a radioimmunoassay. Total GLP-1 (i.e. the sum of intact GLP-1 and its metabolite GLP-1 9-36 amide) was measured using an antiserum specific for C-terminal in GLP-1 (no. 89390) ${ }^{(18)}$. Likewise, an antiserum specific for C-terminal in GIP (code no. 867) was used for total GIP. Free AA from plasma were analysed using an in-solutionchloroformate derivatisation after $\mathrm{pH}$ adjustment to 5-6 using $100 \mu \mathrm{l}$ of $7 \mathrm{~m} \mathrm{NaOH}$, followed by chloroform extraction as performed by Qiu et al. ${ }^{(19)}$ with minor changes. The obtained ethyl esters were separated on a HP-5ms capillary column coated with polyimide $(60 \mathrm{~m} \times 0.25 \mathrm{~mm}$ internal diameter, $0.25 \mu \mathrm{m}$ film thickness (Agilent Technologies)) and quantified on a $7890 \mathrm{~A}$ GC system coupled with a 5975c inert mass selective detector (MSD) quadrupole mass spectrometer (Agilent Technologies). Protein powders were hydrolysed and subsequently analysed in the same way as plasma samples.

\section{Statistical analysis and calculations}

The statistical power calculation was based on our primary effect parameter, viz. TAG incremental AUC (iAUC). The number of participants needed to obtain a statistical power of $80 \%$ at a level of $P<0.05(\alpha=0.05,1-\beta=0.8)$ was 16 . The anticipated dropout level was set at $20 \%$. Descriptive statistics are presented as means with $95 \% \mathrm{CI}$, unless otherwise stated. Statistical analyses were performed in STATA/IC 14.2 (StataCorp), and graphics were made in GraphPad Prism 7.0
(GraphPad Software Inc.). We calculated iAUC (TAG, insulin, glucagon, glucose, GLP-1, GIP, S-paracetamol and AA) using the trapezoid model. Total AUC (tAUC) was used for NEFA. Student's $t$ test was applied to compare the difference in iAUC and tAUC for biochemical parameters regarding timing. Oneway ANOVA was used for comparison of differences in iAUC and tAUC for biochemical parameters and AA regarding protein types. We applied ANOVA for repeated measurements to examine the effect of the intervention (pre-meal) and time on postprandial responses. Subject and day were used as random variables, order as covariates, and lipid-lowering drugs as systematic variables. Statistically significant differences at individual time points were analysed by estimates for linear combinations and indicated in figures by letters. $P<0.05$ was considered statistically significant. Validation was performed by inspecting quantile-quantile plots, histograms and BlandAltman plots.

\section{Results}

Table 2 presents the participants' baseline characteristics. A total of twenty-eight subjects were screened, twenty were randomised and sixteen completed the study. Screening was unsuccessful in eight subjects. In all, four withdrew after randomisation for personal reasons. Table 3 shows the effect of timing and protein type during the postprandial period, and Table 4 shows the means of iAUC and tAUC for the biochemical parameters.

\section{TAG and NEFA}

The concentration of TAG in the four groups peaked after $240 \mathrm{~min}$. None of the participants in the four groups had returned to fasting TAG values $360 \mathrm{~min}$ after ingestion of the fatrich main meal. Fig. 1(a) shows that the postprandial TAG response was independent of the type of protein pre-meal $(P=0.95)$ and its timing $(P=0 \cdot 87)$. TAG iAUC were also similar.

We observed similar postprandial NEFA suppressions in all four groups; suppression reached a minimum at $60 \mathrm{~min}$ and returned to fasting levels at $360 \mathrm{~min}$ (Fig. 1(b)). Timing $(P=0.22)$ or pre-meal type $(P=0.79)$ had no effect.

Table 2. Baseline characteristics of the sixteen subjects with the metabolic syndrome

(Mean values and 95\% confidence intervals)

\begin{tabular}{|c|c|c|}
\hline \multirow[b]{2}{*}{ Characteristic } & \multicolumn{2}{|c|}{ Total group } \\
\hline & Mean & $95 \% \mathrm{Cl}$ \\
\hline Sex, females/males & \multicolumn{2}{|c|}{$6 / 10$} \\
\hline Age (years) & 65.4 & $62 \cdot 0,68 \cdot 8$ \\
\hline Weight (kg) & 88.7 & $79 \cdot 9,97 \cdot 6$ \\
\hline BMI $\left(\mathrm{kg} / \mathrm{m}^{2}\right)$ & 29.6 & $27 \cdot 5,31 \cdot 7$ \\
\hline Waist:hip ratio & 0.968 & $0.932,1.00$ \\
\hline Systolic blood pressure (mmHg) & $136 \cdot 6$ & $129 \cdot 1,144 \cdot 2$ \\
\hline Diastolic blood pressure $(\mathrm{mmHg})$ & $81 \cdot 8$ & $77 \cdot 2,86 \cdot 5$ \\
\hline Glucose $(\mathrm{mmol} / \mathrm{l})$ & 6.02 & $5 \cdot 73,6 \cdot 30$ \\
\hline TAG $(\mathrm{mmol} / \mathrm{l})$ & 1.56 & $1 \cdot 10,2 \cdot 02$ \\
\hline HDL-cholesterol (mmol/l) & 1.48 & $1 \cdot 25,1 \cdot 70$ \\
\hline
\end{tabular}


Table 3. Effect of timing and protein type: postprandial concentration of biochemical parameters after consumption of a whey protein (WP) pre-meal 15 or 30 min before a fat-rich main meal, or a pre-meal of casein or gluten protein in subjects with the metabolic syndrome $(n 16)$

(Medians, mean values and $95 \%$ confidence intervals)

\begin{tabular}{|c|c|c|c|c|c|c|c|c|c|c|c|}
\hline \multirow[b]{3}{*}{ Parameter (unit) } & \multirow[b]{3}{*}{ Time (min) } & \multicolumn{8}{|c|}{ Intervention (pre-meal) } & \multirow[b]{3}{*}{ Timing $(P)^{\star}$} & \multirow[b]{3}{*}{ Protein type $(P) \dagger$} \\
\hline & & \multicolumn{2}{|c|}{ WP $(-15 \mathrm{~min})$} & \multicolumn{2}{|c|}{ WP $(-30 \mathrm{~min})$} & \multicolumn{2}{|c|}{ Casein } & \multicolumn{2}{|c|}{ Gluten } & & \\
\hline & & Median & $95 \% \mathrm{Cl}$ & Median & $95 \% \mathrm{Cl}$ & Median & $95 \% \mathrm{Cl}$ & Median & $95 \% \mathrm{Cl}$ & & \\
\hline \multirow[t]{3}{*}{ TAG $(\mathrm{mmol} / \mathrm{l})$} & Fasting $(-15 /-30 \mathrm{~min})$ & 1.60 & $1.46,1.75$ & 1.52 & $1.38,1.66$ & 1.57 & $1.43,1.72$ & 1.54 & $1.40,1.68$ & 0.8668 & 0.9541 \\
\hline & 240 & 2.91 & $2 \cdot 65,3 \cdot 18$ & 2.84 & $2 \cdot 58,3 \cdot 10$ & 2.85 & $2.60,3.11$ & 2.77 & $2.52,3.02$ & & \\
\hline & 360 & 2.45 & $2 \cdot 23,2 \cdot 68$ & 2.37 & $2 \cdot 15,2 \cdot 58$ & 2.36 & $2 \cdot 14,2 \cdot 57$ & 2.48 & $2 \cdot 26,2 \cdot 71$ & & \\
\hline \multirow[t]{3}{*}{ NEFA $(\mathrm{mmol} / \mathrm{l})$} & Fasting $(-15 /-30 \mathrm{~min})$ & 0.51 & $0.45,0.57$ & 0.50 & $0.44,0.55$ & 0.46 & $0.41,0.51$ & 0.47 & $0.41,0.52$ & 0.2164 & 0.7891 \\
\hline & 60 & 0.16 & $0.14,0.17$ & 0.15 & $0.13,0.16$ & 0.15 & $0.14,0.17$ & 0.18 & $0.16,0.20$ & & \\
\hline & 360 & 0.57 & $0.50,0.63$ & 0.55 & $0.49,0.61$ & 0.52 & $0.46,0.58$ & 0.53 & $0.47,0.59$ & & \\
\hline \multirow[t]{3}{*}{ Insulin (pmol/l) } & Fasting $(-15 /-30 \mathrm{~min})$ & 79.0 & $65 \cdot 9,92 \cdot 1$ & $81 \cdot 8$ & $68 \cdot 2,95 \cdot 4$ & 83.1 & $69.3,96 \cdot 9$ & 59.8 & $49 \cdot 8,69 \cdot 8$ & 0.0001 & 0.0062 \\
\hline & 15 & $408 \cdot 8^{\mathrm{a}}$ & $340 \cdot 8,476.8$ & 349.9 & $291 \cdot 6,408 \cdot 1$ & $374 \cdot 1^{\mathrm{a}}$ & $311 \cdot 8,436.3$ & $253 \cdot 3^{\mathrm{b}}$ & $211 \cdot 1,295 \cdot 5$ & & \\
\hline & 120 & $214 \cdot 8$ & $179.1,250.5$ & 199.4 & $166 \cdot 2,232 \cdot 6$ & 186.5 & $155.5,217.5$ & 171.0 & $142.5,199.4$ & & \\
\hline \multirow[t]{3}{*}{ Glucagon (pg/ml) } & Fasting $(-15 /-30 \mathrm{~min})$ & $78 \cdot 3$ & $72 \cdot 4,84 \cdot 1$ & 81.5 & $75 \cdot 4,87 \cdot 6$ & 77.8 & $71 \cdot 9,83.6$ & 75.6 & $69 \cdot 9,81 \cdot 3$ & $<0.0001$ & $<0.0001$ \\
\hline & 15 & $151 \cdot 9^{\mathrm{a}}$ & $140 \cdot 5,163 \cdot 3$ & $145 \cdot 3$ & $134 \cdot 3,156 \cdot 2$ & $146 \cdot 8^{\mathrm{a}}$ & $135 \cdot 7,157.8$ & $115 \cdot 0^{\mathrm{b}}$ & $106 \cdot 3,123 \cdot 6$ & & \\
\hline & 120 & 111.8 & $103 \cdot 4,120 \cdot 2$ & 113.6 & $105 \cdot 0,122 \cdot 1$ & $117 \cdot 7$ & $108 \cdot 8,126 \cdot 5$ & $107 \cdot 3$ & $99 \cdot 2,115 \cdot 4$ & & \\
\hline \multirow[t]{8}{*}{ Glucose $(\mathrm{mmol} / \mathrm{l})$} & Fasting $(-15 /-30 \mathrm{~min})$ & & & & & & & & & 0.3990 & 0.9333 \\
\hline & Mean & \multirow{2}{*}{\multicolumn{2}{|c|}{$\begin{array}{c}5.73 \\
5.49,5.98\end{array}$}} & \multirow{2}{*}{\multicolumn{2}{|c|}{$\begin{array}{c}5.74 \\
5.49,5.99\end{array}$}} & \multicolumn{2}{|c|}{$\begin{array}{c}5 \cdot 61 \\
5 \cdot 37,5 \cdot 87\end{array}$} & \multicolumn{2}{|c|}{$\begin{array}{c}5 \cdot 64 \\
5 \cdot 39 \quad 5.89\end{array}$} & & \\
\hline & $\begin{array}{c}95 \% \mathrm{Cl} \\
30\end{array}$ & & & & & &, 5.87 & &, 5.89 & & \\
\hline & Mean & \multirow{3}{*}{\multicolumn{2}{|c|}{$\begin{array}{c}5 \cdot 73 \\
5 \cdot 49,5 \cdot 98\end{array}$}} & \multirow{2}{*}{\multicolumn{2}{|c|}{$\begin{array}{c}5.69 \\
5.44,5.94\end{array}$}} & \multirow{2}{*}{\multicolumn{2}{|c|}{$\begin{array}{c}5 \cdot 88 \\
5 \cdot 63,6 \cdot 13\end{array}$}} & \multicolumn{2}{|c|}{6.02} & & \\
\hline & $95 \% \mathrm{Cl}$ & & & & & & & & 6.27 & & \\
\hline & 120 & & & \multirow{2}{*}{\multicolumn{2}{|c|}{5.58}} & & & & & & \\
\hline & Mean & \multicolumn{2}{|c|}{$5 \cdot 41$} & & & \multicolumn{2}{|c|}{5.39} & \multicolumn{2}{|c|}{5.41} & & \\
\hline & $95 \% \mathrm{Cl}$ & & 5.66 & & $3,5 \cdot 83$ & & 5.64 & & 5.66 & & \\
\hline GLP-1 (pmol/l) & Fasting $(-15 /-30 \mathrm{~min})$ & 13.6 & $12 \cdot 4,14 \cdot 8$ & 12.5 & $11.4,13.6$ & $13 \cdot 1$ & $11 \cdot 9,14 \cdot 2$ & $13 \cdot 2$ & $12 \cdot 0,14 \cdot 4$ & 0.4826 & 0.6188 \\
\hline & 120 & 33.6 & $30 \cdot 7,36 \cdot 6$ & $30 \cdot 7$ & $28.0,33.5$ & 30.6 & $27 \cdot 8,33 \cdot 3$ & 33.1 & $30 \cdot 1,36 \cdot 0$ & & \\
\hline & 360 & $15 \cdot 2$ & $13 \cdot 8,16 \cdot 5$ & $16 \cdot 2$ & $14.7,17.6$ & 17.5 & $16 \cdot 0,19 \cdot 1$ & $16 \cdot 9$ & $15 \cdot 4,18 \cdot 4$ & & \\
\hline GIP (pmol/l) & Fasting $(-15 /-30 \mathrm{~min})$ & 8.4 & $6.8,9.9$ & 8.3 & $6.8,9.9$ & 8.6 & $7 \cdot 0,10 \cdot 2$ & 6.9 & $5 \cdot 7,8 \cdot 2$ & 0.0789 & 0.0103 \\
\hline & 120 & $82 \cdot 4$ & $67 \cdot 0,97 \cdot 7$ & $73 \cdot 3$ & $59 \cdot 6,87.0$ & 79.1 & $64.4,93.8$ & $65 \cdot 3$ & $53 \cdot 1,77 \cdot 5$ & & \\
\hline & 360 & 31.5 & $25 \cdot 3,37 \cdot 4$ & $32 \cdot 8$ & $26 \cdot 7,38 \cdot 9$ & $42 \cdot 3$ & $34.4,50 \cdot 2$ & $32 \cdot 0$ & $26 \cdot 0,37 \cdot 9$ & & \\
\hline Paracetamol $(\mu \mathrm{mol} / \mathrm{l})$ & 30 & & & & & & & & & 0.0013 & 0.3986 \\
\hline & Mean & & 0.6 & & 94.6 & & 3.4 & & $02 \cdot 3$ & & \\
\hline & $\begin{array}{c}95 \% \mathrm{Cl} \\
120\end{array}$ & & 76.9 & & $110 \cdot 9$ & & $109 \cdot 7$ & & 118.6 & & \\
\hline & Mean & & $6 \cdot 0$ & & $72 \cdot 0$ & & 4.6 & & 7.3 & & \\
\hline & $95 \% \mathrm{Cl}$ & & $102 \cdot 3$ & & $7,88 \cdot 3$ & & $100 \cdot 9$ & & 93.6 & & \\
\hline
\end{tabular}

GLP-1, glucagon-like polypeptide 1; GIP, gastric inhibitory polypeptide.

*

was to test whether the response curves for the two interventions (WP $(-15 \mathrm{~min})$ and WP $(-30 \mathrm{~min}))$ during the postprandial period were parallel.

† ANOVA for repeated measurements. The hypothesis was to test whether the response curves for the three interventions (WP ( -15 min), casein or gluten) during the postprandial period were parallel. 
Table 4. Incremental AUC (iAUC) and total AUC (tAUC) of biochemical parameters and amino acid after consumption of a whey protein (WP) pre-meal 15 or 30 min before a fat-rich main meal, or a pre-meal of casein or gluten protein in subjects with the metabolic syndrome $(n 16)$ (Mean values, medians and $95 \%$ confidence intervals)

\begin{tabular}{|c|c|c|c|c|c|c|c|c|c|c|}
\hline & \multicolumn{8}{|c|}{ Intervention (pre-meal) } & \multirow[b]{3}{*}{ Timing $(P)^{\star}$} & \multirow[b]{3}{*}{ Protein type $(P) \dagger$} \\
\hline & \multicolumn{2}{|c|}{ WP $(-15 \mathrm{~min})$} & \multicolumn{2}{|c|}{ WP $(-30 \mathrm{~min})$} & \multicolumn{2}{|r|}{ Casein } & \multicolumn{2}{|c|}{ Gluten } & & \\
\hline & Mean & $95 \% \mathrm{Cl}$ & Mean & $95 \% \mathrm{Cl}$ & Mean & $95 \% \mathrm{Cl}$ & Mean & $95 \% \mathrm{Cl}$ & & \\
\hline \multicolumn{11}{|l|}{ tAUC } \\
\hline $\begin{array}{l}\text { NEFA, } \mathrm{mmol} / / \mathrm{x}-15 /-30 \text { to } 360 \mathrm{~min} \\
\text { AAUC }\end{array}$ & 138.1 & $128 \cdot 1,148 \cdot 0$ & 140.9 & $130 \cdot 9,150 \cdot 8$ & $130 \cdot 5$ & $120 \cdot 6,140 \cdot 5$ & $132 \cdot 2$ & $122 \cdot 3,142 \cdot 2$ & 0.7233 & 0.4792 \\
\hline TAG, mmol/lx-15/-30 to $360 \mathrm{~min}$ & 250.2 & $197.6,302.8$ & 256.9 & $204.3,309 \cdot 4$ & 243.8 & $191 \cdot 2,296 \cdot 3$ & 242.5 & $189 \cdot 9,295 \cdot 0$ & 0.8659 & 0.9740 \\
\hline Insulin, pmol//x-15/-30 to $360 \mathrm{~min}$ & 43539.8 & $33753 \cdot 6,53325.9$ & 39974 & $30187.8,49760.2$ & 38511.9 & $28398.0,48625.8$ & 38777.3 & $28663,48891 \cdot 2$ & 0.6026 & 0.7296 \\
\hline Glucagon, $\mathrm{pg} / \mathrm{ml} \times-15 /-30$ to $360 \mathrm{~min}$ & 10717.7 & $8155.4,13280.0$ & 10497.2 & $7987.6,13006 \cdot 7$ & 11457.9 & $8718 \cdot 7,17197.2$ & $11392 \cdot 7$ & $8669 \cdot 0,14116 \cdot 3$ & 0.8839 & 0.9110 \\
\hline Glucose, $\mathrm{mmol} / / \mathrm{x}-15 /-30$ to $360 \mathrm{~min}$ & 158.6 & $132 \cdot 9,184.4$ & 156.6 & $125 \cdot 3,186 \cdot 8$ & 122.6 & $96 \cdot 9,148 \cdot 3$ & $133 \cdot 3$ & $107 \cdot 6,159 \cdot 0$ & 0.9036 & 0.1336 \\
\hline $\mathrm{GLP}-1, \mathrm{pmol} / \mathrm{x}-15 /-30$ to $360 \mathrm{~min}$ & 4052.4 & $3163.0,4941.9$ & $4048 \cdot 1$ & $3158 \cdot 7,4937.6$ & 4300.7 & $3411.3,5190 \cdot 1$ & 4194.5 & $3305 \cdot 1,5083 \cdot 9$ & 0.9942 & 0.9263 \\
\hline GIP, pmol///x-15/-30 to $360 \mathrm{~min}$ & 16986.8 & $14076 \cdot 2,19897 \cdot 4$ & 17759.9 & $14849 \cdot 3,20670.5$ & 18039.8 & $15129 \cdot 2,20950 \cdot 4$ & $15404 \cdot 4$ & $12493 \cdot 8,18315 \cdot 0$ & 0.7274 & 0.4049 \\
\hline Paracetamol $\neq, \mu \mathrm{mol} / / \mathrm{x}-15 /-30$ to $360 \mathrm{~min}$ & $19202 \cdot 6$ & $16345 \cdot 6,22059.5$ & 22771.7 & $19383.7,26159.6$ & $21026 \cdot 7$ & $17898 \cdot 3,24155 \cdot 0$ & 21031.6 & $17902.5,24160.7$ & 0.1896 & 0.6087 \\
\hline \multirow{3}{*}{$\begin{array}{l}\text { Leu, } \mu \mathrm{gg} / \mathrm{mg} \times-15 /-30 \text { to } 360 \mathrm{~min} \\
\text { lle, } \mathrm{gg} / \mathrm{mg} \times-15 /-30 \text { to } 360 \mathrm{~min} \\
\text { Median } \\
95 \% \mathrm{Cl}\end{array}$} & $57173 \cdot 8^{\mathrm{a}}$ & $48817.5,65530.0$ & - & & $46660 \cdot 3^{a}$ & $38304.0,55016.6$ & $33787.8^{b}$ & $25431 \cdot 5,42144 \cdot 1$ & - & 0.0006 \\
\hline & 202500 a & & - & & 然 & & & & - & $<0.0001$ \\
\hline & $38350 \cdot 9^{\mathrm{a}}$ & 22768.7 .42933 .1 & & & $28641.8^{\circ}$ & 24059.6 .33224 .0 & $20752 \cdot 8^{c}$ & $16170.6,25335.0$ & & \\
\hline \multirow{3}{*}{$\begin{array}{l}\text { Val, } \mu \mathrm{g} / \mathrm{mg} \times-15 /-30 \text { to } 360 \mathrm{~min} \\
\text { Lys, } \mu \mathrm{g} / \mathrm{mg} \times-15 /-30 \text { to } 360 \mathrm{~min} \\
\text { Median } \\
95 \% \mathrm{Cl}\end{array}$} & $53233.6^{a}$ & $45119 \cdot 4,51347 \cdot 9$ & - & & $56105 \cdot 6^{a}$ & $47991 \cdot 3,64219 \cdot 8$ & $32447 \cdot 3^{\mathrm{b}}$ & $24333.0,40561.6$ & - & 0.0002 \\
\hline & $901 \cdot 0^{\mathrm{a}}$ & & & & $960 \cdot 5^{a}$ & & $535 \cdot 5^{\mathrm{b}}$ & & - & 0.0411 \\
\hline & & $571.5,1230.5$ & & & & $609 \cdot 0,1311 \cdot 7$ & & $339 \cdot 7,731 \cdot 3$ & & \\
\hline Thr, $\mu \mathrm{g} / \mathrm{mg} \times-15 /-30$ to $360 \mathrm{~min}$ & $21684 \cdot 8^{\mathrm{a}}$ & $19019 \cdot 8,24278 \cdot 7$ & - & & $15726 \cdot 8^{8}$ & $13132 \cdot 8,18320 \cdot 7$ & $11536 \cdot 7^{c}$ & $8942 \cdot 7,14130 \cdot 6$ & - & $<0.0001$ \\
\hline
\end{tabular}

GLP-1, glucagon-like polypeptide 1; GIP, gastric inhibitory polypeptide.

a,b,c Values within a row with unlike superscript letters were significantly different $(P<0.05)$

* Student's $t$ test was applied for analysing differences on the postprandial responses.

† One-way ANOVA was applied for analysing differences on the postprandial responses. The hypothesis was to test whether iAUC or tAUC was significantly different between the three interventions WP (-15 min), casein and gluten. The hypothesis was to test whether iAUC or tAUC was significantly different between WP (-15 min) and WP $(-30 \mathrm{~min})$.

† For paracetamol, $n 15$. 
(a)

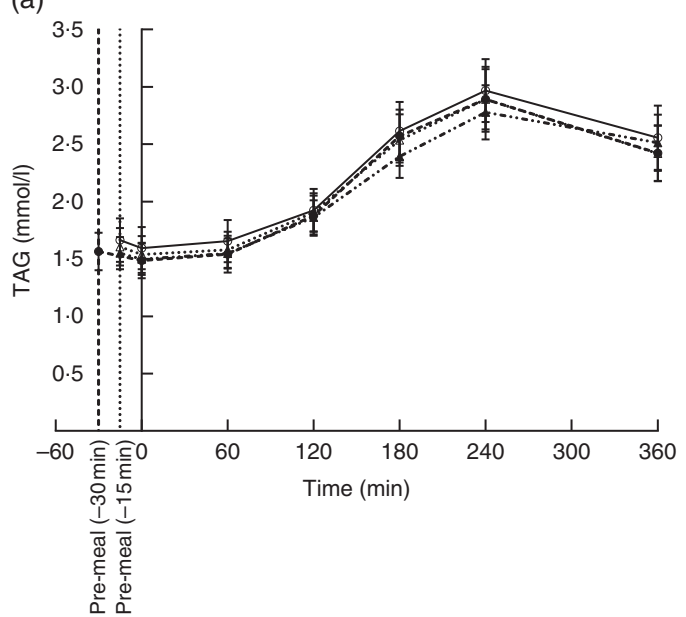

(b)

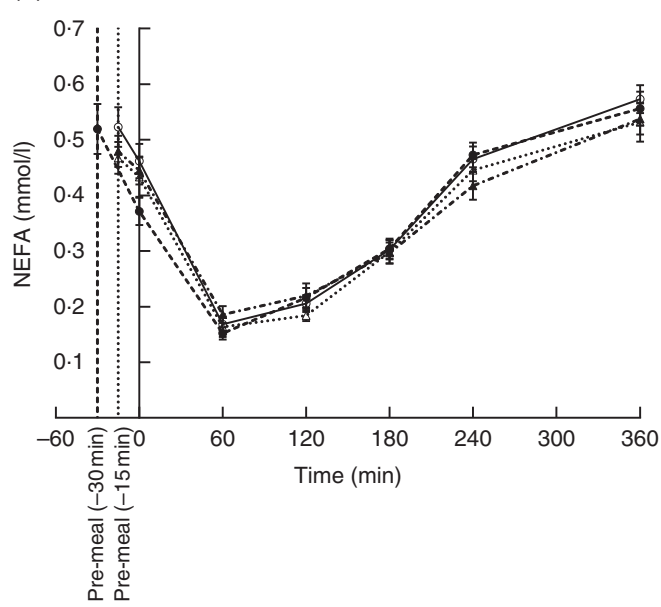

Fig. 1. Postprandial plasma responses of TAG (a) and NEFA (b) after ingestion of pre-meal of whey protein (WP), casein or gluten 15 min prior, or WP 30 min before a fat-rich meal. Values are means $(n 16)$, with their standard errors represented by vertical bars. Data were analysed using ANOVA for repeated measurement to

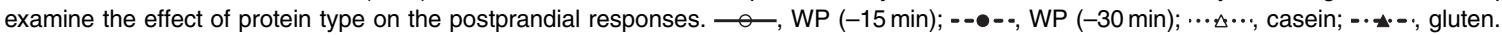

\section{Insulin, glucagon and glucose}

The insulin concentration increased after consumption of all four pre-meals (Fig. 2(a)). WP ( $-15 \mathrm{~min})$, WP (-30 min) and casein induced maximum insulin concentrations after $15 \mathrm{~min}$, whereas gluten reached maximum insulin concentration at time point $30 \mathrm{~min}$. Insulin concentrations returned to normal fasting ranges in all four groups after $360 \mathrm{~min}$. We observed a significant effect of timing $(P=0.0001)$ and protein quality $(P=0.0062)$ during the response period. The time course for gluten was different from that of WP $(P=0.0008)$ and casein $(P=0.008)$ due to the lower insulin concentrations at time points 0 and $15 \mathrm{~min}$. The groups did not differ with regard to iAUC.

Plasma glucagon increased in all four groups and reached a maximum $15 \mathrm{~min}$ after the main meal and returned to near fasting values after $360 \mathrm{~min}$ (Fig. 2(b)). Both timing $(P<0.0001)$ and protein type $(P<0.0001)$ affected the glucagon secretion pattern, but the iAUC were similar in the groups. The early response to gluten was smaller than the early response to WP $(P<0.0001)$ and casein $(<0 \cdot 0001)$. The glucose responses for the four groups fluctuated between 5.1 and $6.3 \mathrm{mmol} / \mathrm{l}$ during the postprandial period at $0-120 \mathrm{~min}$ (Fig. 2(c)). After $120 \mathrm{~min}$, blood glucose was stable around $5.5 \mathrm{mmol} / \mathrm{l}$ in all four groups. We observed no effect of timing $(P=0.40)$ or protein quality $(P=0.93)$, and AUC were similar.

\section{Incretins (glucose-dependent insulinotropic peptide and glucagon-like peptide 1)}

GIP concentrations increased immediately after consumption of the pre-meals and peaked after $120 \mathrm{~min}$ (Fig. 3(a)) and had returned to fasting levels in any of the groups even at $360 \mathrm{~min}$. The protein type affected the progression curve for GIP $(P=0 \cdot 0103)$. Gluten was significantly different from WP $(P=0.0298)$ and casein $(P=0.0036)$, due to a steeper rise in GIP after milk-protein pre-meals. However, timing had no effect
$(P=0 \cdot 08)$, and the iAUC did not differ significantly among the interventions.

For GLP-1, the response profiles were similar in the four groups (Fig. 3(b)). Maximum concentrations reached after $120 \mathrm{~min}$. Thus, neither timing nor protein type had an effect on GLP-1.

\section{S-paracetamol}

The S-paracetamol concentration rose shortly after the main meal in all four groups and reached maximum at $60 \mathrm{~min}$ (Fig. 4). Paracetamol was lower after WP $(-15 \mathrm{~min})$ than after WP $(-30 \mathrm{~min})$ at $15 \mathrm{~min}$ after the main meal $(P=0.028)$. At time point $30 \mathrm{~min}$, the concentration of $\mathrm{S}$-paracetamol was significantly higher in the casein $(P=0.031)$ and gluten $(P=0.007)$ group than in the WP group. Neither timing nor protein quality had any effect on iAUC paracetamol.

\section{Free amino acids}

A total of twenty free AA were detectable in plasma after ingestion of the four pre-meals, both at fasting $(-15 \mathrm{~min})$ and at time points 60 and $360 \mathrm{~min}$ (Table 4 and online Supplementary Table S1). WP was rich in BCAA, threonine and lysine (Table 1). iAUC differed significantly between the three different protein types regarding valine $(P=0.0002)$, leucine $(P=0.0006)$, isoleucine $(P<0.0001)$, lysine $(P=0.0411)$ and threonine $(P<0 \cdot 0001)$ and was higher after WP than after gluten. Also, iAUC for isoleucine and threonine were higher for WP than for casein.

\section{Discussion}

In this study, we examined how PPL was affected by the time between a pre-meal and a fat-rich test meal as well as by the protein type of the pre-meal before a fat-rich meal. 

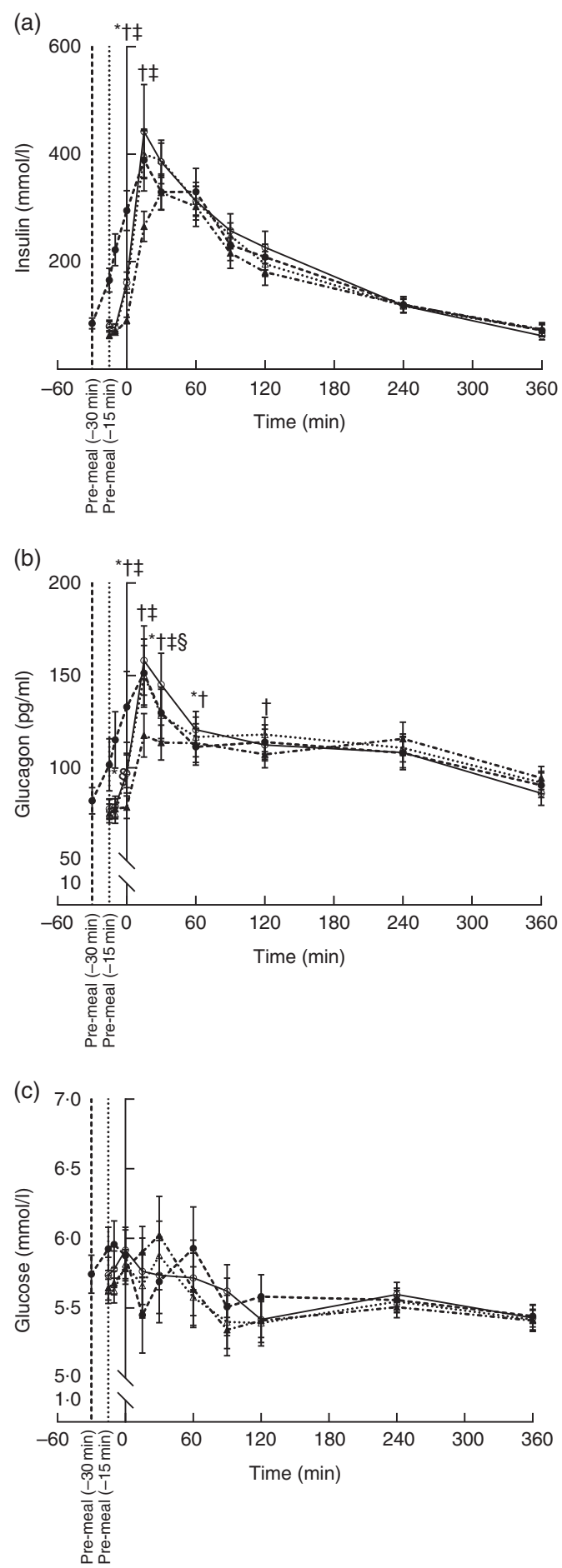

Fig. 2. Postprandial plasma responses of insulin (a), glucagon (b) and glucose (c) after ingestion of pre-meal of whey protein (WP), casein or gluten $15 \mathrm{~min}$ prior, or WP $30 \mathrm{~min}$ before a fat-rich meal. Values are means $(n 16)$, with their standard errors represented by vertical bars. Data were analysed using ANOVA for repeated measurement to examine the effect of protein type on the postprandial responses. Significant differences $(P<0.05)$ : * WP $(-15 \mathrm{~min}) v$. WP $(-30 \mathrm{~min})$, †WP $v$. gluten, $\ddagger$ casein $v$. gluten, §WP $v$. casein. —— WP $(-15 \mathrm{~min})$;

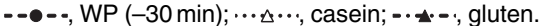

Interestingly, we found that the timing and the protein quality of the pre-meal had no effect on our primary outcome, that is,
TAG responses. In contrast, both the timing and the protein type of the pre-meal ( $17.6 \mathrm{~g}$ pure protein) modified pancreatic hormone secretion (insulin and glucagon) in subjects with the MetS. Furthermore, we found that gastric emptying was more delayed after a pre-meal with WP $(-15 \mathrm{~min})$ than after a premeal with casein, gluten or WP ( $-30 \mathrm{~min})$.

We expected to find a difference in TAG responses, since the potent insulinotropic effect of a WP pre-meal could induce larger reductions in TAG responses due to the stimulated lipolytic activity of lipoprotein lipase ${ }^{(15)}$. Previous studies show that $45 \mathrm{~g}$ WP consumed as a part of a fat-rich meal reduces postprandial TAG responses compared with other protein types (casein, gluten and cod protein) in subjects with and without $\mathrm{T}_{2} \mathrm{D}^{(15,16,20)}$. In contrast, Mariotti et al. ${ }^{(21)}$ showed that due to physiochemical properties, $45 \mathrm{~g}$ casein induced a significantly larger reduction in TAG than WP in overweight men. Interestingly, we found no difference in either lipid responses or NEFA suppression between the intervention groups. It is likely that these discrepancies are caused by the difference in total protein content. This might indicate that the effective WP threshold for TAG suppression is somewhere between 20 and $45 \mathrm{~g} \mathrm{WP}$. We here chose to use $17.6 \mathrm{~g}$ pure protein, because this is a realistic maximum dose to consume as a pre-meal since $17.6 \mathrm{~g}$ pure protein corresponds to $20 \mathrm{~g} \mathrm{WP}$, which we also used in a previous study $^{(17)}$. In the present study, we compared a $20 \mathrm{~g}$ WP pre-meal to a pre-meal with no protein and therefore did not include $0 \mathrm{~g}$ in the present study.

Acute human studies show that WP has a more potent insulinotropic effect than other protein types ${ }^{(11-13)}$. We confirmed these findings by showing that WP preferentially stimulated insulin secretion. Insulin stimulation was also affected by the timing, with consumption of WP $30 \mathrm{~min}$ before the fatrich meal generating earlier insulin stimulation than consumption of WP ( $-15 \mathrm{~min})$ before the meal. This was reflected in the significantly higher insulin concentration at time point $0 \mathrm{~min}$ (just before consumption of the main meal) and may explain the time-to-intervention interaction observed. We chose to serve the pre-meal at time point -30 and $-15 \mathrm{~min}$, because these are the time points at which diabetics treated with meal-time insulin usually administered before a meal. A further advantage of these time points is that they reflect preferred routines since medicine adherence improves if the medicine is taken close to meals. WP and casein amplified insulin secretion more than gluten within the first $30 \mathrm{~min}$ after consumption of a pre-meal. We expected to observe a difference between WP and casein due to their different solubility and hence faster absorption ${ }^{(22)}$, but this was not found. An explanation could be that larger protein doses are needed to reveal differences in insulin responses. However, a recent study showed that co-ingestion of $50 \mathrm{~g}$ WP or casein with maltodextrin caused no difference in insulin response ${ }^{(23)}$. It is well known that insulin and glucagon are co-secreted in response to consumption of proteins and single $\mathrm{AA}^{(24,25)}$. In agreement with this, we observed that all three protein types stimulated glucagon secretion and more so for WP and casein than for gluten. The AA composition demonstrated in plasma may explain this co-secretion and the higher insulin and glucagon concentrations after the milk protein pre-meal. The iAUC for BCAA, lysine and threonine after 
(a)

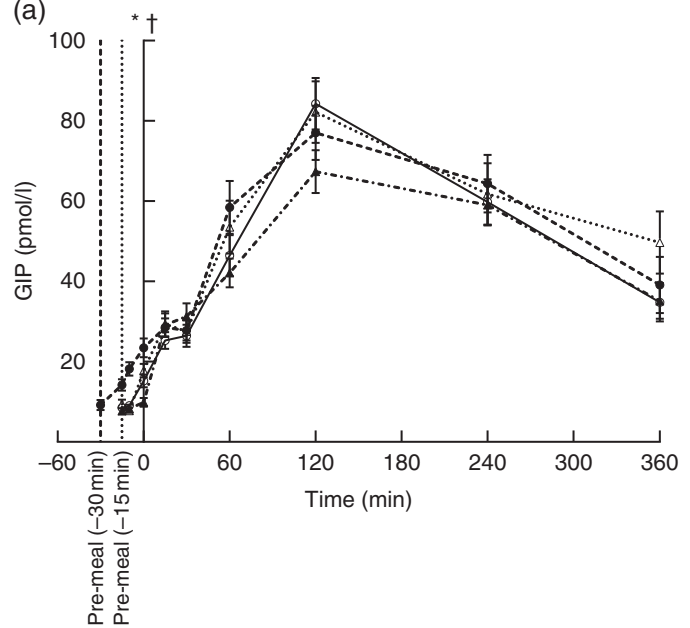

(b)

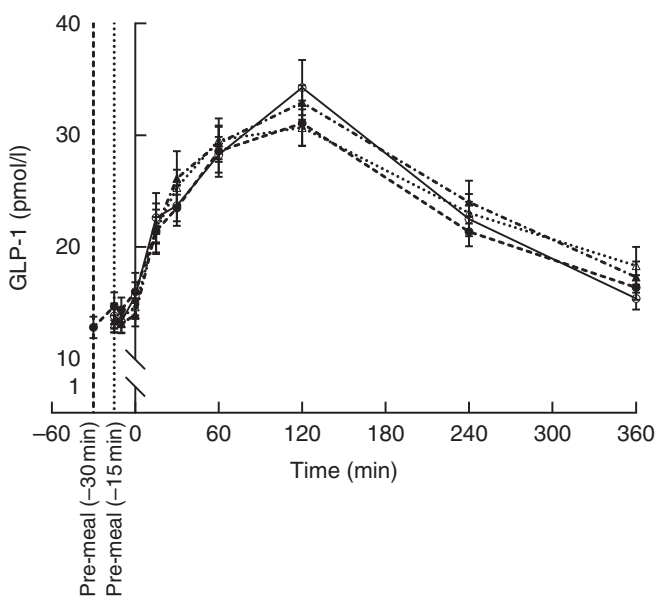

Fig. 3. Postprandial plasma responses of glucose-dependent insulinotropic peptide (GIP) (a) and glucagon-like peptide 1 (GLP-1) (b) after ingestion of pre-meal of whey protein (WP), casein or gluten $15 \mathrm{~min}$ prior, or WP $30 \mathrm{~min}$ before a fat-rich meal. Values are means $(n 16)$, with their standard errors represented by vertical bars. Data were analysed using ANOVA for repeated measurement to examine the effect of protein type on the postprandial responses. Significant differences $(P<0.05)$ :

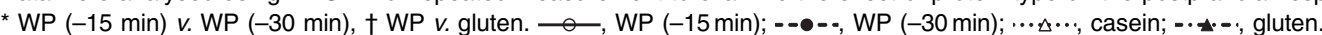

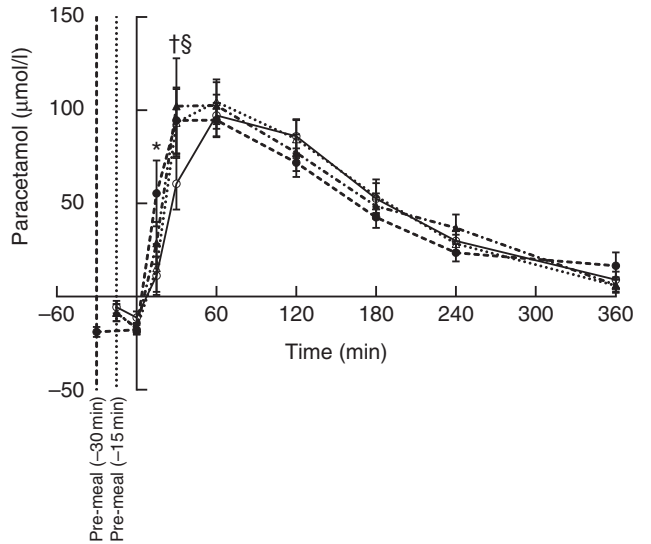

Fig. 4. Postprandial plasma responses of paracetamol after ingestion of premeal of whey protein (WP), casein or gluten $15 \mathrm{~min}$ prior, or WP $30 \mathrm{~min}$ before a fat-rich meal. Values are means ( $n$ 15), with their standard errors represented by vertical bars. Data were analysed using ANOVA for repeated measurement to examine the effect of protein type on the postprandial responses. Significant differences $(P<0.05):{ }^{*}$ WP $(-15 \mathrm{~min}) v$. WP $(-30 \mathrm{~min})$, † WP v. gluten, § WP $v$. casein. $\multimap$, WP $(-15 \mathrm{~min}) ;--\bullet-.$, WP $(-30 \mathrm{~min})$; $\cdots \Delta \cdots$, casein; ......, gluten.

the meal were significantly higher for WP and casein than for gluten (Table 4 and online Supplementary Table S1). These five AA play a key role in the insulinotropic response ${ }^{(14)}$. In the present study, the protein quality affected GIP; however, the mechanism of action is currently unknown.

We did expect a suppression of blood glucose levels secondary to the insulin stimulation observed; however, glucose responses were influenced neither by timing nor by protein quality. This is in accordance with the previous studies reporting similar effects on blood glucose of WP and casein at doses between 16.2 and $55 \mathrm{~g}$ when proteins are consumed before a carbohydrate-rich meal or as part of the meal ${ }^{(7,20,23,26)}$. However, we previously demonstrated that $45 \mathrm{~g}$ WP consumed as a part of fat-rich meal lowered glucose iAUC more than casein, gluten and cod protein ${ }^{(16)}$. The discrepancy between the results in the present study and our previous study ${ }^{(16)}$ may at least partially be related to the differences in the amounts of protein, as the amount of protein affects the insulin response, or to the differences in the fat composition of the meals. In the present study, we included $70 \mathrm{~g}$ fat per meal to exceed the normal lipoprotein capacity. Such a fat-rich test meal is obviously not applicable to everyday life but is recognised as a suitable way of studying $\operatorname{PPL}^{(16,27)}$.

We used paracetamol as an indicator of the liquid phase gastric emptying. Paracetamol was administered to the fat-rich meals. It is likely that the large amount of fat $(70 \mathrm{~g}$ fat) contributes to a delay in gastric emptying and did so to the same extent in the four pre-meal situations. The WP $(-15 \mathrm{~min})$ pre-meal delayed gastric emptying more compared with the WP (-30 min) pre-meal. Furthermore, the paracetamol concentrations were lower $30 \mathrm{~min}$ postprandially for WP compared with casein and gluten, illustrating a delayed gastric emptying. This is in agreement with previous studies demonstrating that a WP pre-meal delays gastric emptying ${ }^{(10,17)}$, but it is a new observation that the duration of the time gap between the pre-meal and the main meal also affects gastric emptying. It is likely that the AA level is higher before the meal when WP is given $30 \mathrm{~min}$ before the fat-rich mean compared with when it is given $15 \mathrm{~min}$ before. This may partly explain the difference in gastric emptying. Thus, we previously found that the BCAA, isoleucine, was higher after WP than after gluten and casein and that it was associated with a delayed gastric emptying ${ }^{(28)}$. Interestingly, Ma et $a l .{ }^{(29)}$ recently showed that the ability to reduce postprandial glycaemia and delay gastric emptying was maintained in T2D subjects after intervention with $25 \mathrm{~g}$ WP as a pre-meal for 4 weeks.

One of the main strength of the present study was its randomised, crossover study design where each participant served as his or her own matched control. In addition, we used protein types applied in daily life that were easy to eat. 
In conclusion, intake of $17.6 \mathrm{~g}$ protein pre-meal did not alter the lipid response (TAG and NEFA) to a fat-rich meal, and we must therefore reject our hypothesis. However, we demonstrated that hormone secretion (insulin and glucagon) depends on both pre-meal timing and protein quality. A WP pre-meal consumed $30 \mathrm{~min}$ before a meal stimulated hormone responses earlier than WP consumed 15 min before a meal. WP and casein displayed more potent insulinotropic actions compared with gluten protein. Finally, our results support that a WP pre-meal consumed $15 \mathrm{~min}$ before the fat-rich meal delays gastric emptying more than a WP pre-meal consumed $30 \mathrm{~min}$ before the meal.

\section{Acknowledgements}

The authors would like to extend our gratitude to Eva Mølgaard Jensen, Lene Trudsø Jensen and Lene Bruus Albæk for outstanding technical assistance. Furthermore, we are grateful for the assistance provided by Annemarie Kruse, Peter Reiter, Mette Bohl and Anne Grethe Schioldan during the meal tests. Milk protein powder was kindly provided by Arla Foods Ingredients Group P/S and Arla Foods amba. Gluten protein powder was kindly provided by Lantmännen.

This work was supported by grants from the Danish Dairy Research Foundation, Arla Foods Ingredients Group P/S and the Innovation Fund DK - MERITS (grant no. 4105-00002B). A. B. was supported by research grants from the Danish Diabetes Academy supported by the Novo Nordisk Foundation, Aarhus University and the Research Foundation of the Department of Endocrinology and Internal Medicine, Aarhus University Hospital. J. J. H. was supported by the Novo Nordisk Foundation.

A. B. and K. H. raised the research question and designed the study; A. B. and T. N. J. carried it out; A. B., T. N. J. and K. H. analysed the data; B. A., T. K. D. and J. J. H. contributed reagents/materials/analysis tools; A. B. wrote the article.

A. B., T. N. J., B. A., T. K. D., J. J. H. and K. H. have no conflicts of interest and other funding disclosures to declare.

\section{Supplementary material}

For supplementary material/s referred to in this article, please visit https://doi.org/10.1017/S0007114518003264

\section{References}

1. Alberti KG, Eckel RH, Grundy SM, et al. (2009) Harmonizing the metabolic syndrome: a joint interim statement of the International Diabetes Federation Task Force on Epidemiology and Prevention; National Heart, Lung, and Blood Institute; American Heart Association; World Heart Federation; International Atherosclerosis Society; and International Association for the Study of Obesity. Circulation 120, 1640-1645.

2. Nordestgaard BG, Benn M, Schnohr P, et al. (2007) Nonfasting triglycerides and risk of myocardial infarction, ischemic heart disease, and death in men and women. JAMA 298, 299-308.

3. Bansal S, Buring JE, Rifai N, et al. (2007) Fasting compared with nonfasting triglycerides and risk of cardiovascular events in women. JAMA 298, 309-316.
4. Staub H (1921) Untersuchungen uber den Zuckerstoffwechsel des Munchen (Studies on sugar metabolism of humans). Z Klin Med 91, 44-48.

5. Traugott K (1922) Über das Verhalten des Blutzuckerspiegels bei Wiederholter und Verschiedener Art Enteraler Zuckerzufuhr und Dessen Bedeutung für die Leberfunktion. (About the behavior of blood sugar level in repeated and different types of enteral sugar intake and their importance for liver function). Klin Wochenschr 1, 892-894.

6. Akhavan T, Luhovyy BL, Brown PH, et al. (2010) Effect of premeal consumption of whey protein and its hydrolysate on food intake and postmeal glycemia and insulin responses in young adults. Am J Clin Nutr 91, 966-975.

7. Gunnerud UJ, Heinzle C, Holst JJ, et al. (2012) Effects of premeal drinks with protein and amino acids on glycemic and metabolic responses at a subsequent composite meal. PLOS ONE 7, e44731.

8. Akhavan T, Luhovyy BL, Panahi S, et al. (2014) Mechanism of action of pre-meal consumption of whey protein on glycemic control in young adults. $J$ Nutr Biochem 25, 36-43.

9. Clifton PM, Galbraith C \& Coles L (2014) Effect of a low dose whey/guar preload on glycemic control in people with type 2 diabetes - a randomised controlled trial. Nutr J 13, 103.

10. Ma J, Stevens JE, Cukier K, et al. (2009) Effects of a protein preload on gastric emptying, glycemia, and gut hormones after a carbohydrate meal in diet-controlled type 2 diabetes. Diabetes Care 32, 1600-1602.

11. Nilsson M, Stenberg M, Frid AH, et al. (2004) Glycemia and insulinemia in healthy subjects after lactose-equivalent meals of milk and other food proteins: the role of plasma amino acids and incretins. Am J Clin Nutr 80, 1246-1253.

12. Morifuji M, Ishizaka M, Baba S, et al. (2010) Comparison of different sources and degrees of hydrolysis of dietary protein: effect on plasma amino acids, dipeptides, and insulin responses in human subjects. I Agric Food Chem 58, 8788-8797.

13. Pal S \& Ellis V (2010) The acute effects of four protein meals on insulin, glucose, appetite and energy intake in lean men. Br J Nutr 104, 1241-1248.

14. Nilsson M, Holst JJ \& Bjorck IM (2007) Metabolic effects of amino acid mixtures and whey protein in healthy subjects: studies using glucose-equivalent drinks. Am J Clin Nutr 85 , 996-1004.

15. Mortensen LS, Hartvigsen ML, Brader LJ, et al. (2009) Differential effects of protein quality on postprandial lipemia in response to a fat-rich meal in type 2 diabetes: comparison of whey, casein, gluten, and cod protein. Am J Clin Nutr 90, 41-48.

16. Holmer-Jensen J, Mortensen LS, Astrup A, et al. (2013) Acute differential effects of dietary protein quality on postprandial lipemia in obese non-diabetic subjects. Nutr Res 33, 34-40.

17. Bjornshave A, Holst JJ \& Hermansen K (2018) Pre-meal effect of whey proteins on metabolic parameters in subjects with and without type 2 diabetes: a randomized, crossover trial. Nutrients 10, 122.

18. Kuhre RE, Wewer Albrechtsen NJ, Hartmann B, et al. (2015) Measurement of the incretin hormones: glucagon-like peptide-1 and glucose-dependent insulinotropic peptide. J Diabetes Complications 29, 445-450.

19. Qiu Y, Su M, Liu Y, et al. (2007) Application of ethyl chloroformate derivatization for gas chromatography-mass spectrometry based metabonomic profiling. Anal Chim Acta 583, 277-283.

20. Pal S, Ellis V \& Ho S (2010) Acute effects of whey protein isolate on cardiovascular risk factors in overweight, postmenopausal women. Atherosclerosis 212, 339-344. 
21. Mariotti F, Valette M, Lopez C, et al. (2015) Casein compared with whey proteins affects the organization of dietary fat during digestion and attenuates the postprandial triglyceride response to a mixed high-fat meal in healthy, overweight men. J Nutr 145, 2657-2664.

22. Boirie Y, Dangin M, Gachon P, et al. (1997) Slow and fast dietary proteins differently modulate postprandial protein accretion. Proc Natl Acad Sci U S A 94, 14930-14935.

23. Hoefle AS, Bangert AM, Stamfort A, et al. (2015) Metabolic responses of healthy or prediabetic adults to bovine whey protein and sodium caseinate do not differ. $J$ Nutr 145, $467-475$.

24. Unger RH (1971) Glucagon physiology and pathophysiology. $N$ Engl J Med 285, 443-449.

25. Gannon MC \& Nuttall FQ (2010) Amino acid ingestion and glucose metabolism - a review. IUBMB Life 62, 660-668.
26. Bowen J, Noakes M, Trenerry C, et al. (2006) Energy intake, ghrelin, and cholecystokinin after different carbohydrate and protein preloads in overweight men. J Clin Endocrinol Metab 91, 1477-1483.

27. Kolovou GD, Mikhailidis DP, Kovar J, et al. (2011) Assessment and clinical relevance of non-fasting and postprandial triglycerides: an expert panel statement. Curr Vasc Pharmacol 9, 258-270.

28. Stanstrup J, Schou SS, Holmer-Jensen J, et al. (2014) Whey protein delays gastric emptying and suppresses plasma fatty acids and their metabolites compared to casein, gluten, and fish protein. J Proteome Res 13, 2396-2408.

29. Ma J, Jesudason DR, Stevens JE, et al. (2015) Sustained effects of a protein 'preload' on glycaemia and gastric emptying over 4 weeks in patients with type 2 diabetes: a randomized clinical trial. Diabetes Res Clin Pract 108, e31-e34. 